\title{
The State of Manufacturing in Pakistan
}

\section{Rajah Rasiah* and Nazia Nazeer**}

\begin{abstract}
The history of successful industrializers, such as South Korea and Taiwan, shows a systematic shift in the production structure from low- to highvalue added activities in manufacturing and its resulting impact on agriculture, mining and services. Within manufacturing, the transformation is seen in both a movement from low-value added sectors, such as apparel making, to high-tech activities, such as automotive and electronics products, and, within particular industries, vertical integration into knowledge-intensive activities.

Pakistan's failure to engender the conditions to stimulate technological upgrading within its leading manufacturing industry of clothing, and a shift away to higher-value added industries is the prime reason why the country has not achieved rapid growth in GDP per capital over the long-term. This paper discusses Pakistan's stagnation in manufacturing over the period 1960-2013 against the experience of the rapid industrializers of South Korea, Taiwan and Malaysia. Drawing on empirical evidence it argues that Pakistan requires a dynamic industrial policy that focuses on technological upgrading in its existing manufacturing sectors and the creation of competitive advantage in high valueadded sectors if the country is to experience sustained long-term economic growth.
\end{abstract}

Keywords: Manufacturing, industries, policy, Pakistan.

JEL classification: L60, O25.

\section{Introduction}

Pakistan has a rich history of producing and exporting cotton and cotton-based goods. Following independence in 1947, much was expected of the country, given that it was endowed with reasonable levels of human capital compared to other newly independent countries at the time. However, Pakistan has remained a poor country, so much so that its per

\footnotetext{
* Department of Development Studies, University of Malaya.

** Department of Economics, University of Malaya.

We have benefited enormously from conversations with and suggestions from Irfan ul Haque, Naved Hamid, Shahid Amjad Chaudhry, Azam Chaudhry, and Khalil Hamdani. The usual disclaimer applies.
} 
capita income grew only about fourfold from US\$ 219 in 1960 to US\$ 790 in 2013 in constant 2005 prices (World Bank, 2014). This growth does not compare well with that achieved by South Korea and other rapid industrializers such as Malaysia, Thailand, and China. Korea's per capita income (in 2005 prices) rose by around 22 times from US\$ 1,107 in 1960 to US\$ 23,893 in 2013. Malaysia's GDP per capita grew sevenfold from US\$ 987 in 1960 to US\$ 6,998 in 2013. Thailand's GDP per capita grew eightfold from US\$ 437 in 1965 to US\$3,348 in 2013. China's GDP per capita growth significantly surpassed that of Malaysia and Thailand, growing by 15 times from US\$ 246 in 1982 to US\$ 3,567 in 2013.

Cotton-related clothing has remained Pakistan's chief export, even in 2014, unlike the case of successful industrializers, where clothing eventually became relatively less significant as they shifted toward high value-added economic activities. This contrasting growth experience largely explains why material living conditions in Pakistan have not improved significantly. This paper examines possible economic reasons for why the country was unable to join the Asian "tigers" to achieve long-term rapid economic growth. We analyze the structural changes that pushed Pakistan toward manufacturing activities, and within manufacturing from low- to medium- and high-technology activities. We also assess the extent of technological upgrading achieved in its chief export - clothing.

Section 2 discusses the theoretical issues relevant to analyzing the state of manufacturing in Pakistan. Section 3 presents the methodology and data used. Section 4 examines the state of manufacturing in Pakistan with a special focus on its leading industries - textiles and clothing. Section 5 presents the study's conclusions.

\section{Theoretical Considerations}

Industrial policy has a long history: the first instance is considered to have originated accidentally in Britain in the 15th century (Reinert, 2007). Early efforts to define industrial policy referred to the term as a policy or set of policies targeted at expanding industry in general and manufacturing in particular (Kaldor, 1967). While some economists, such as Young (1928) and Kaldor (1957), focused on the differentiating characteristics of industrialization and its impact on the division of labor and economic expansion, they did not specifically analyze the technological deepening and structural change from low- to high-value added activities that is essential for manufacturing to remain an engine of growth. 
As Rowthorn $(1975,1979)$ shows, Kaldor's growth equations that were run to establish the increasing returns argument using Verdoorn's law were flawed. Nonetheless, the idea that manufacturing is an important driver of economic growth - at least during the development phase of particular economies of reasonable size and population - has strong support from classic texts such as Smith (1776), Hamilton (1791), and List (1885) and from contemporary studies such as Chang (2002) and Reinert (2007).

There is also strong empirical evidence to support the increasing returns argument associated with manufacturing (see Kaldor, 1967; Singh, 1989; Rasiah, 1994, 1996). Since industrialization is expected to remain important (positive) even when deindustrialization sets in, it is possible to examine the elasticity of GDP per capita with respect to manufacturing per capita even for developed countries, although knowledge-based services are expected to overtake manufacturing as the prime engine of growth. This becomes clear when we regress manufacturing value added per capita on the GDP per capita growth rates for all countries for which data are available over the period 2000-10 (see Figure 1).

Figure 1: Relationship between GDP per capita and manufacturing value-added per capita growth rates, 2000-10 (elasticities)

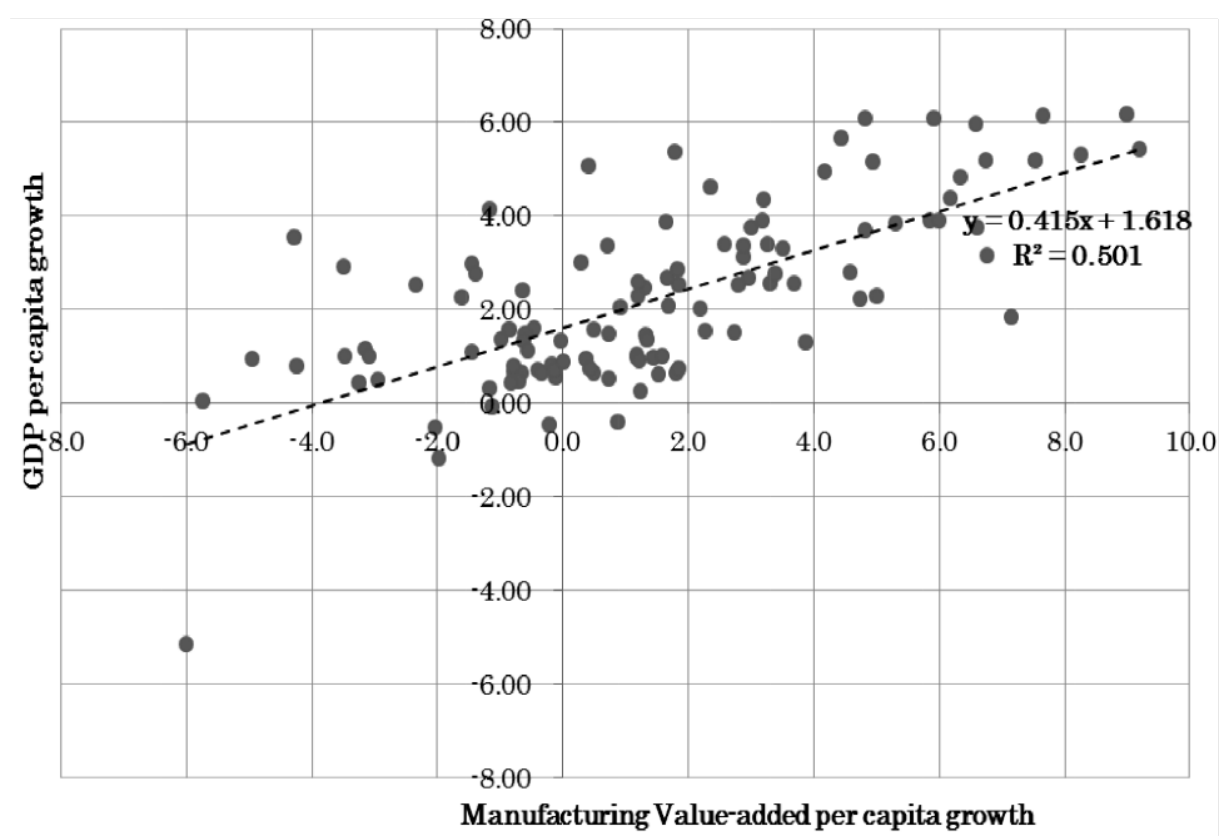

Source: Authors' calculations based on World Bank data (2014). 
Although, in this case, several countries had already developed by the turn of the millennium and a number of economies are small and resource-driven, the relationship between GDP per capita and manufacturing value added per capita growth rates (estimated using 2005 prices) remains strong. Since the constant is not significant and the coefficient of $x$ is significant at the 1 percent level, a one-percent rise in manufacturing value added per capita will generate a 0.4 percent rise in GDP per capita.

While Chenery, Robinson, and Syrquin (1986) attempt to analyze structural change within manufacturing, they confine their analysis to categorization by capital goods, consumer durables, intermediate goods, and raw materials. Feldman (1928), Kalecki (1976), and Mahalanobis (1955) have presented growth accumulation models that target the capital goods industry. Lall (2000) subsequently classifies industries as high-tech, medium-tech, and low-tech to address the sophistication of countries' economic structures. However, these classifications do not address innovation and technology directly.

The transformation of production into different stages and the evolution of embodied knowledge in which the depth of innovation transcends the nature and type of goods and services means that it no longer matters whether countries experience structural transformation by way of specializing in consumer to intermediate to capital goods. For example, Taiwan and Singapore show greater specialization in components and intermediate goods than Malaysia, but are technologically superior to the latter, which is reflected in their respective value-added activities. Hence, a successful industrial policy should be viewed as an exercise used to successfully stimulate sustainable economic transformation from low- to high-value added activities of targeted (as well as other) industries in the economy.

Classic works such as Marx (1957), Veblen (1915), and Schumpeter (1961) laid the foundation for an assessment of technology. Subsequently, Rosenberg's (1983) unbundling of the "black box" led to a plethora of work defining technological capabilities (see, for example, Dahlman, 1984; Bell, 1984; Lall, 1992). Rasiah $(2007,2008)$ extends the typologies necessary to locate the technological capabilities of firms and differentiate their position using taxonomies and trajectories against the world's frontier firm in particular industries. Rather than defining these typologies in static terms, Rasiah (2007, 2008) follows Nelson's (2008) argument that typologies change with time, location, and industry. Rasiah (2004) does not regard 
investment capability as an integral part of technological capabilities, given that the chaebols and large integrated circuit (IC) firms in Taiwan were launched through heavy government financing.

The catch-up literature, which has its origins in Marx's notion of capitalist integration and accumulation, expanded with Veblen (1915), Gerschenkron (1962), and Abramowitz (1956). These works gave rise to the idea that the state has a developmental function beyond its regulatory role. The empirical foundations of the developmental state articulating the active role of government in stimulating industrial structural change can be found in works explaining industrial catch-up by Japan and Korea (see Johnson, 1982; Amsden, 1989; Wade, 1990). However, while Amsden (1989) and Amsden and Chu (2003) provide explicit accounts of catch-up in particular industries, Johnson (1982) and Wade (1990) do not present empirical evidence on innovation and technology against the particular industrial policy pursued by Japan and Taiwan, respectively.

Industrial deepening has also benefited from institutional change led by the government (Fagerberg, 2006). The innovation system comprises a country's institutions, its political progression, infrastructure for research and development (R\&D), financial setup, and labor force, all of which influence the way it generates, distributes, attains, and utilizes knowledge. Global knowledge is one of the strongest tools to facilitate technological change through foreign direct investment (FDI), the transfer of technology, licensing technology and trade. As Amsden (1989) argues succinctly, latecomer economies have benefited from acquiring and adapting imported technology from developed countries to spearhead their catch-up process (see also Rasiah, Singh, \& Ernst, 2015). The relationship between the national innovation system and import substitution industrialization (ISI) helps balance science, technology, and innovation policies in emerging economies. Moreover, these linkages could support sufficient understanding to enable interaction among global institutional factors, collaboration in R\&D, and the migration and return migration of knowledge workers.

Taking our cue from these accounts, we examine how Pakistan's manufacturing sector has evolved since the 1960s and its relationship with GDP per capita against selected countries. The next section presents our methodology for analyzing Pakistan's industrialization experience. 


\section{Methodology and Data}

The first part of the analysis examines the link between manufacturing and GDP per capita, using selected countries for which data are available, to establish the significance of manufacturing as an engine of GDP per capita growth. We use the years 1970, 1990, and 2013 to establish this link. The assessment will allow us to explain why Pakistan's GDP per capita only increased about fourfold over the period 1960-2013, while that of the rapid industrializers, such as South Korea and China, rose far more.

The second methodology examines changes in value added and exports of manufacturing based on Lall's (2000) classification of high-tech, medium-tech, and low-tech industries. The data for manufactured exports and production in Pakistan is analyzed for the period 1960-2013 to examine the extent of structural shift experienced by the country. This is then compared with selected countries for years for which data is available.

The third exercise seeks to analyze the extent of structural change experienced by Pakistan's dominant manufacturing industry - textiles and clothing - over the period 1970-2010. Diversification into upstream and downstream activities is classified as functional integration within the industry (see Figure 2).

Figure 2: Percentage share of manufacturing in GDP for selected countries, 1965-2013

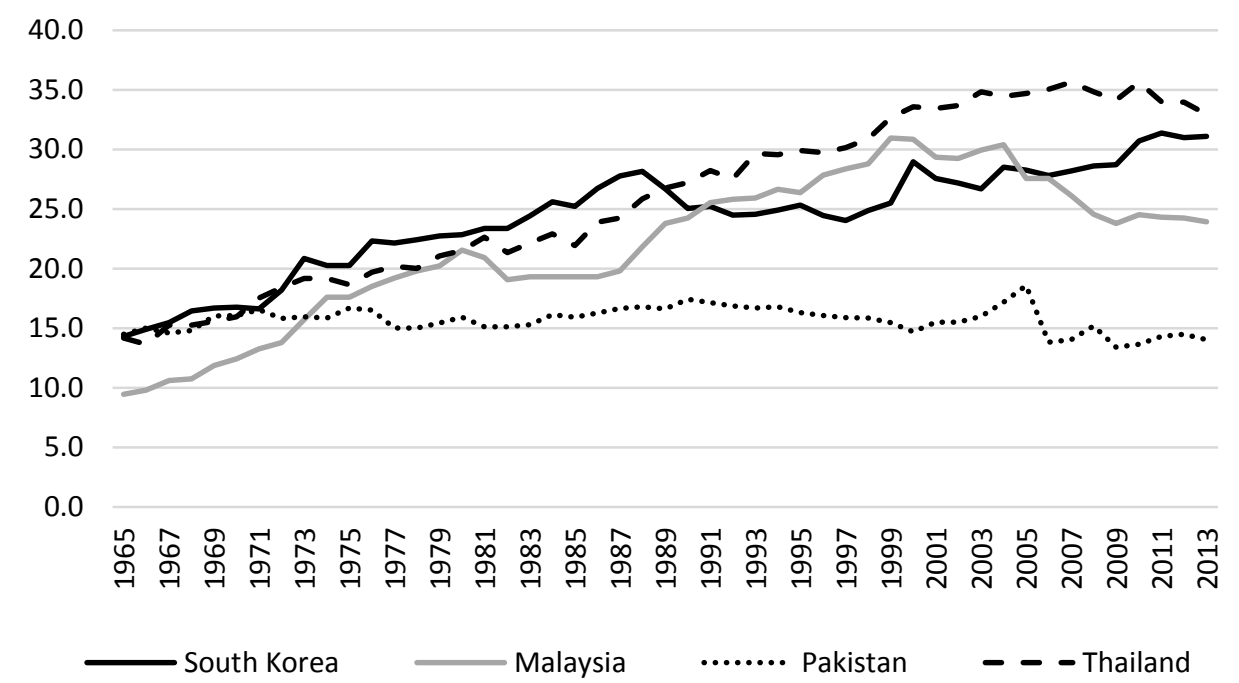

Source: Authors' calculations based on World Bank data (2014). 
Functional upgrading is considered to be taking place if the structural shift within the industry involves downstream integration from cotton fiber to yarn, and from yarn to knitted and woven fabrics (Rasiah, Yap, \& Yap, 2015). This also applies if there is increased production of mixed fibers (e.g., cotton and synthetic fiber such as polyester) and its downstream processes such as spinning, and weaving and knitting. However, the data we have does not allow us to distinguish between upgrading and just integration because we lack information on designing, $\mathrm{R} \& \mathrm{D}$, and logistics for both the textiles and clothing industries in Pakistan.

Combining both dimensions of technological upgrading, it is possible to define the technological depth of textiles and clothing firms, albeit without profound coverage of the technological depth of these operations. Hence, it is possible to evaluate the success of industrialization by first examining if inter-sectoral and intra-industry upgrading has taken place in Pakistan's two leading manufacturing industries, i.e., textiles and clothing.

\section{Manufacturing}

Pakistan's turbulent economic history largely explains its uneven economic growth experience. However, fundamental to its slow growth have also been (i) the lack of a strong foundation in manufacturing with little diffusion of new technologies, (ii) firms' inability to access international best practices, and (iii) "brain drain". Not only has manufacturing contributed less to GDP in Pakistan relative to the successful industrializers (South Korea, China, and Malaysia), but it has also started to deindustrialize prematurely before achieving specialization in high-value added activities.

\subsection{Contribution to GDP}

One way to analyze the importance of manufacturing in an economy is to examine its share of GDP and compare changes in this over a period of time with comparable economies. For this purpose, we use South Korea, Malaysia, and Thailand, which either showed lower shares than Pakistan or were similar in 1965 when the host governments had not started focusing seriously on promoting industrialization. The trend shifts are then analyzed against policy focus until 2013.

As Figure 2 shows, Pakistan's (14.5 percent) share of manufacturing value added in GDP exceeded that of South Korea (14.3 
percent), Malaysia (9.5 percent), and Thailand (14.2 percent) in 1965. South Korea's share rose in trend terms to 31.1 percent in 2013, interrupted in the intervening years by imported economic crises. Whereas Malaysia's share rose to 30.9 percent in 2000 before falling to 23.9 percent in 2013, Thailand's share rose steadily to 35.6 percent in 2010 before falling slightly to 32.9 percent in 2013. National firms have continued to shape the technology frontier in a number of industries (e.g., memory chips, shipbuilding, iron and steel, consumer electronics and smartphones) so as to support manufacturing as the prime engine of growth in South Korea.

Among these countries, South Korea's achievement is, by far, the most dramatic: rising manufacturing productivity has propelled the nation into developed country status. Using export-processing zones and FDI as springboards, Malaysia managed to appropriate considerable industrial synergy to fuel its economic growth till 2000. However, slow technological upgrading against soaring production costs cooled down the rate of manufacturing growth during 2000-13. In Thailand's case, extensive focus on supplying East Asian markets through the use of foreign technology in automotive manufacturing and other industries strengthened the manufacturing sector's share of GDP. Against these achievements, Pakistan has performed dismally: low-value added resource processing only raised manufacturing's contribution to 18.6 percent in 2005.

Of the four countries examined, South Korea has enjoyed the most dynamic industrial policy, using a carrot-and-stick approach to good effect to stimulate capital accumulation as the state subsidized the chaebols' forays into high technology and heavy industries to catch up with and leapfrog over incumbents. The diffusion of foreign technology through licensing agreements, acquisition of critical firms, deepening of education and science and technology institutes, and the hiring of nationals carrying tacit knowledge in the industry played a central role in quickening the technological catch-up of South Korean firms. The successful catch-up experience of the chaebols has spearheaded the country's rapid economic growth.

Malaysia's ability to provide excellent basic infrastructure, political stability, and security stimulated the massive relocation of FDI. While this propelled growth and resource rents from natural endowments (e.g., oil and gas, and oil palm) helped make Malaysia a middle-income country, a lack of strong education, and science and technology policies and the ineffective strategies used to import foreign 
technology undermined its capacity to stimulate technological catch-up in high technology and heavy industries (Rasiah, 1995). Thailand has managed to upgrade in light industries, such as jewelry and canned foods, and provided ideal incentives for regional assembly of automobiles by foreign firms. The lack of a dynamic industrial policy focused on learning and technological catch-up has, however, restricted its capacity to stimulate rapid economic growth.

Not only has Pakistan's manufacturing remained in low-value added activities, but it has also failed to stimulate rapid per capita income growth (Figure 3). Manufacturing has suffered from a lack of policy support for technological upgrading, while exchange rates and indirect taxation have undermined resource allocation in the sector. Political instability and lack of security have denied the country the easier route of offering excellent basic infrastructure a la Malaysia to attract FDI. In fact, deindustrialization has emerged in Pakistan prematurely since 1986 with the share of manufacturing falling from 18.6 percent in 2005 to 14.0 percent in 2013.

Figure 3: Manufacturing share of GDP and GDP per capita growth rate, Pakistan, 1968-2013

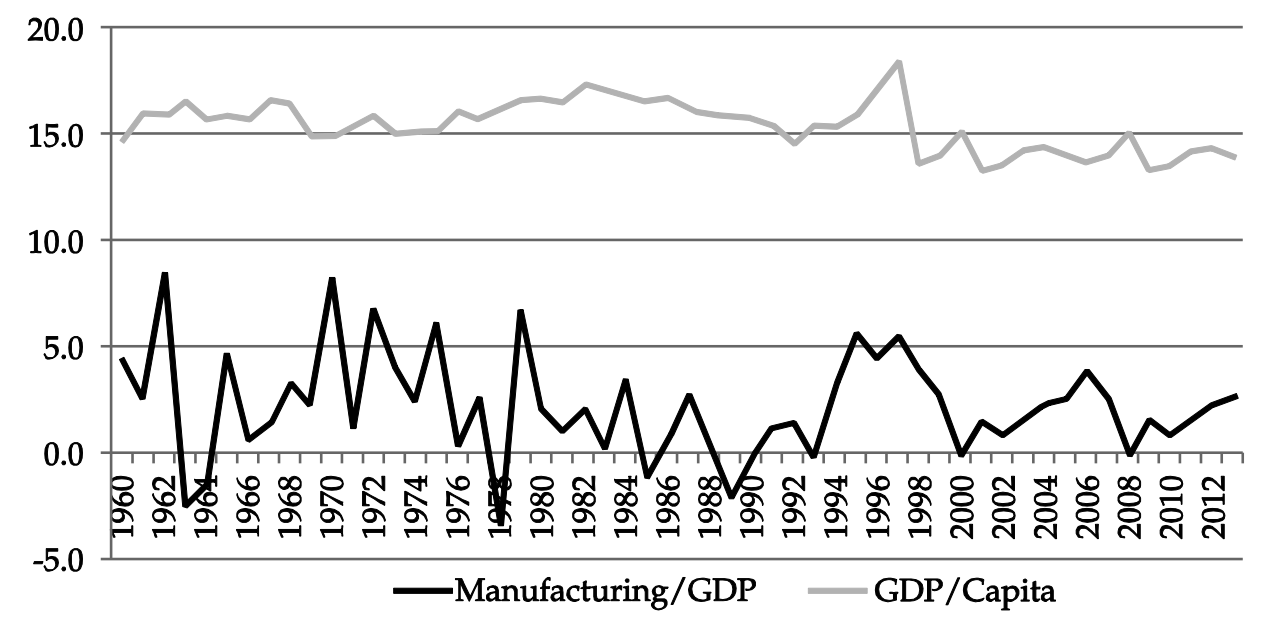

Source: World Bank (2014).

It is obvious that manufacturing has stagnated in Pakistan. While a strategic focus was never applied in the country to fuel manufacturing, the sector has also suffered from a region rife with political instability and insecurity. Hence, manufacturing has hardly evolved to include mediumand high-technology activities, a topic we discuss in the next subsection. 


\subsection{Technological Specialization}

Following Lall's (2000) measure of competitiveness, Pakistan's manufacturing sector demonstrated high growth in medium- and hightechnology industries during 1990-2013 (Figure 4). However, that was only because their starting bases were very small. In addition, mediumand high-technology industries focus on low-end manufacturing activities for the domestic market. Examples include the manufacture of electrical fans. This explains why low technology (LT) industries still account for around 98 percent of Pakistan's manufactured exports (Figure 5). Clearly then, manufacturing has not undergone inter-industry structural change within the sector.

Figure 4: Annual average growth in exports by technological intensity, Pakistan, 1990-2013

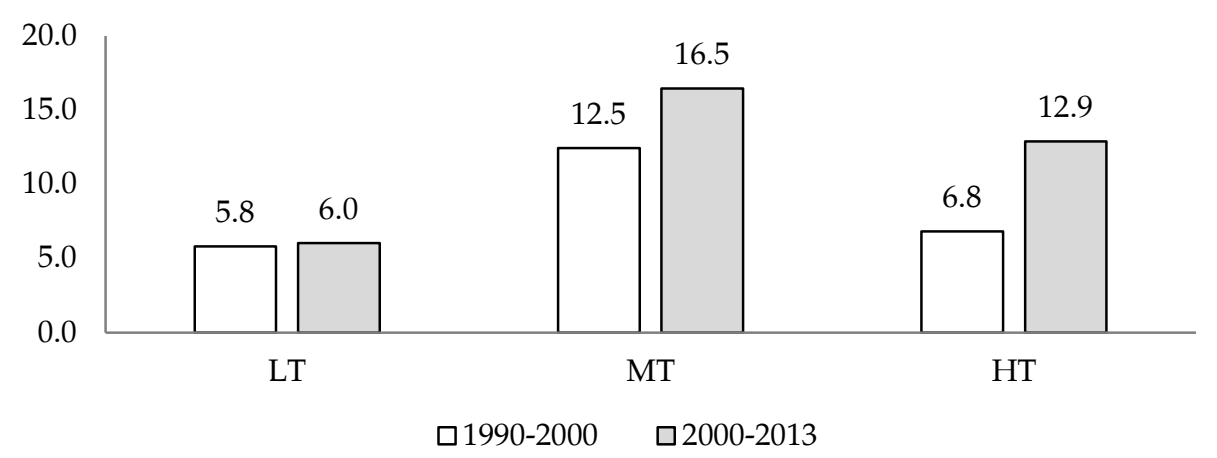

Source: Authors' calculations based on Comtrade data.

Figure 5: Percentage export breakdown by technological intensity, Pakistan, 1990-2013

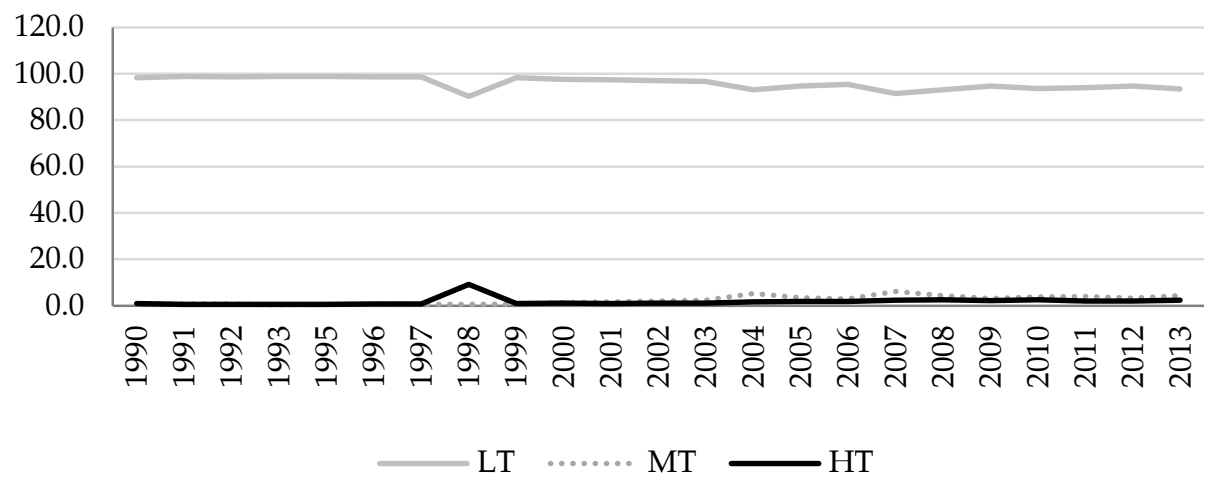

Source: Authors' calculations based on Pakistan Bureau of Statistics data. 


\subsection{Low-End Textile and Cotton Exports}

Whereas textiles and clothing spearheaded early expansion in the manufactured exports of South Korea, China, Malaysia, and Thailand, structural change from low- to medium- and high-value added activities drove down their relative significance in exports. Thus, textiles accounted for only 5.4, 1.0, 3.7, and 2.5 percent in 2005, which fell to 4.8, 0.8, 2.2, and 1.8 percent of overall exports in China, Malaysia, South Korea, and Thailand, respectively, in 2013 (Figure 6). Pakistan's textiles industry remained the cornerstone of manufacturing exports, accounting for 44.2 percent of exports in 2005 and 37.1 percent in 2013. While Pakistan has undergone little industrial structural change, its leading manufactured export, cotton and cotton-based products, has also experienced little vertical and functional upgrading.

Figure 6: Textile exports as a percentage of total exports, selected countries, 2005-13

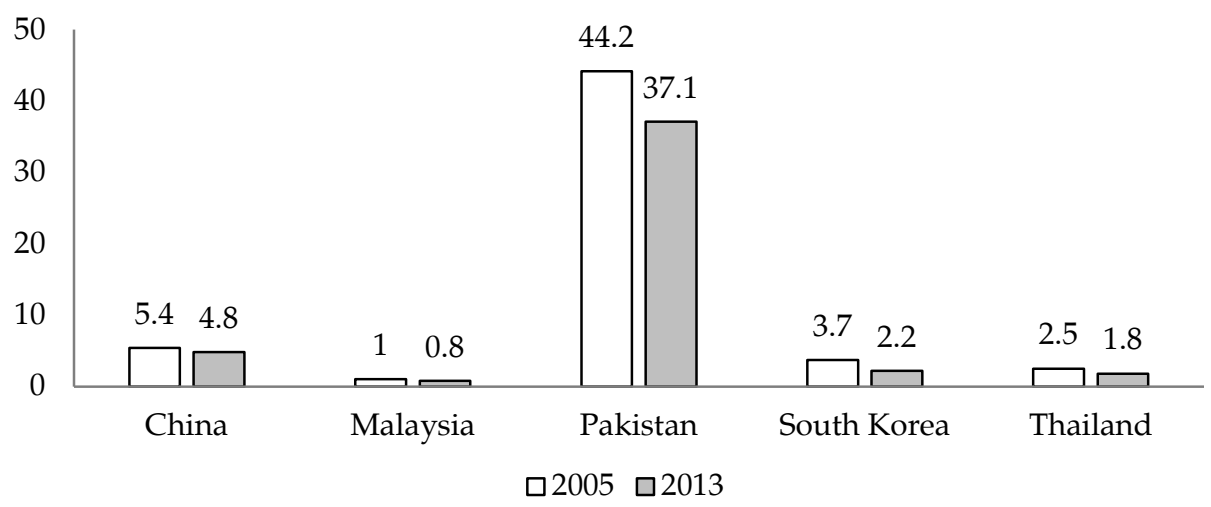

Source: Authors' calculations based on World Trade Organization data $(2008,2014)$.

In addition, clothing accounted for only 8.0, 2.0, 0.4, and 1.8 percent of overall exports for China, Malaysia, South Korea, and Thailand, respectively, in 2013, (having changed from 9.7, 1.8, 0.9, and 3.7 percent in 2005). Pakistan's share of overall exports remained high at 18.1 percent in 2013, falling from 22.5 percent in 2005 (Figure 7). Hence, textiles and clothing together accounted for 55.2 percent of all exports of Pakistan in 2013. 
Figure 7: Clothing exports as a share of total exports, selected countries, 2005-13

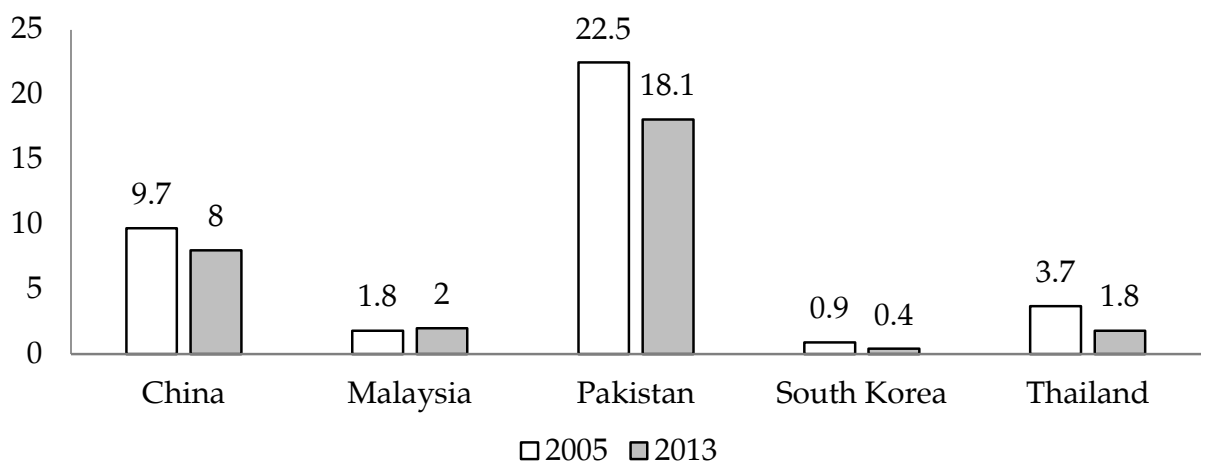

Source: Authors' calculations based on World Trade Organization data $(2008,2014)$.

As an agricultural country, Pakistan produces large amounts of raw wool and cotton to support its textiles and clothing industry. The sector produces five types of fabric: blended, bleached, dyed, printed, and grey (which accounts for about half the overall production). Such an overwhelming dominance of textiles and clothing in Pakistan's exports reflects the lack of industrial policy focus - there has been little shift toward the medium- and high-technology industries. Pakistan's share of textile exports in global exports rose from 1.6 percent in 1980 to 3.1 percent in 2013 (Figure 8), whereas its share of clothing exports in global exports rose from 0.3 percent in 1980 to 1.1 percent in 2000 before falling to 1.0 percent in 2013. Indeed, cotton yarn grew far more than clothing exports over the period 1982-2013 (Figure 9).

Figure 8: Percentage export share of world exports, Pakistan, 1980-13

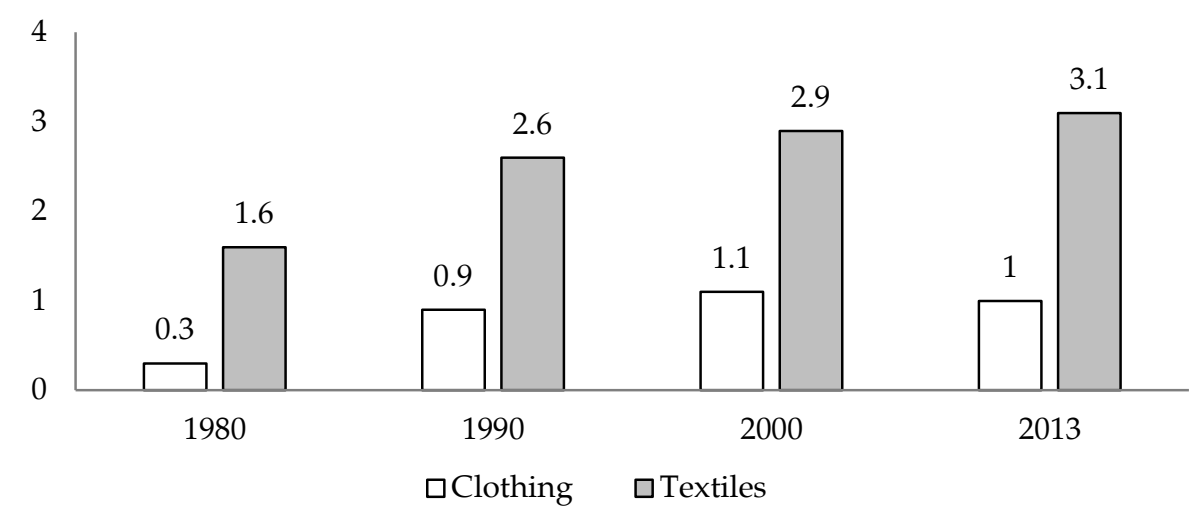

Source: Authors' calculations based on World Trade Organization data (2014). 
Figure 9: Annual growth in cotton yarn and cloth exports, Pakistan, 1982-2013

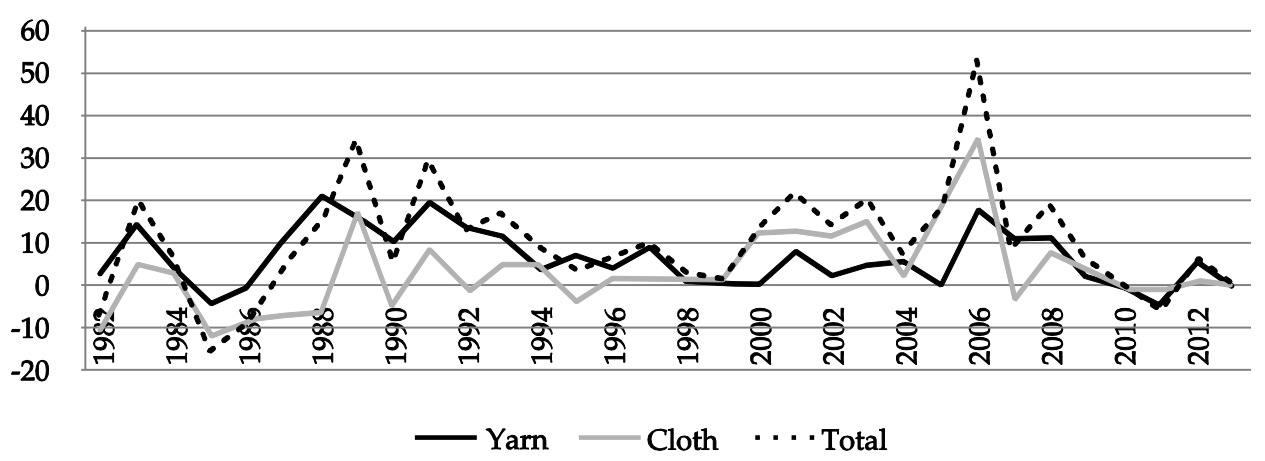

Source: Authors' calculations based on Pakistan Bureau of Statistics data.

Since Pakistan specializes in low-value added textiles (especially in raw fiber and in processed and grey fabric exports) and clothing (Table 1 ), efforts must be made to stimulate upgrading in the industry and to spawn medium- and high-technology industries. For an integrated highvalue added textiles and clothing industry to emerge, the country must stimulate (i) upgrading vertically so as to raise the value added within the textiles and clothing industries, and (ii) functional upgrading to include designing, logistics, and the manufacture of complementary support materials and machinery, such as resins, air-jet looms, auto-fabric scanners, computer-aided design and computer-aided manufacturing machinery (Figure 10).

Table 1: Textiles and clothing exports, Pakistan, 2012-14

\begin{tabular}{lrrrrr}
\hline & \multicolumn{2}{c}{ July-April } & & $\begin{array}{c}\text { Absolute change } \\
\text { Particulars }\end{array}$ & \multicolumn{2}{c}{$\mathbf{2 0 1 2 / 1 3}$} & $\mathbf{2 0 1 3 / 1 4}$ & \%Change & (\$ million) \\
\hline Overall textiles and clothing & $10,739.8$ & $11,437.6$ & 6.5 & 697.8 \\
Raw cotton & 138.3 & 196.1 & 41.8 & 57.8 \\
Cotton yarn & $1,860.5$ & $1,708.1$ & -8.2 & -152.4 \\
Cotton cloth & $2,224.0$ & $2,346.8$ & 5.5 & 122.8 \\
Knitwear & $1,663.6$ & $1,842.1$ & 10.7 & 178.5 \\
Bed wear & $1,468.2$ & $1,767.3$ & 20.4 & 299.1 \\
Towels & 645.0 & 624.5 & -3.2 & -20.5 \\
Readymade garments & $1,470.8$ & $1,580.8$ & 7.5 & 110.0 \\
Made-up articles & 480.8 & 552.1 & 14.8 & 71.3 \\
Other textile manufactures & 788.6 & 819.8 & 4.0 & 31.2 \\
\hline
\end{tabular}

Source: Pakistan Economic Survey 2013/14. 
Pakistan's cotton-based industry is characterized by an integrated production chain - from cotton cultivation to ginning, weaving, knitting, processing, and finishing of fabrics - but little technological upgrading. The industry can only become strongly integrated if it is clustered to include the higher-value added segments of branding and logistics, and the strong presence of machinery and material suppliers (Figure 10). It has been adversely affected by soaring gas and electricity prices, political insecurity, and technological stagnation. The lack of vocational and technical education has restricted the capacity of workers to absorb best practices in the industry, which is critical if the sector is to compete with exports from China, Bangladesh, Cambodia, and India.

Thus, Pakistan's manufacturing is still dominated by lowtechnology textiles and clothing. Indeed, resource-based textiles have been the leading export (exceeding clothing exports), thereby suggesting that little functional upgrading has taken place. High-technology products have been insignificant, while exports of synthetic textiles have led to medium-technology exports performing marginally well in Pakistan. It could learn from Malaysia, the Philippines, and Thailand where high-technology products have become the dominant manufacturing exports. However, while it is good to stimulate structural change into medium- and high-technology industries, Pakistan should not abandon the apparel industry. Instead, it should undertake more designing, R\&D, and brand marketing in the clothing industry, while raising the value added by engaging in the complementary industries of machinery (knitting and weaving machines) and dyes.

Figure 10: Textiles and clothing value chain, 2015

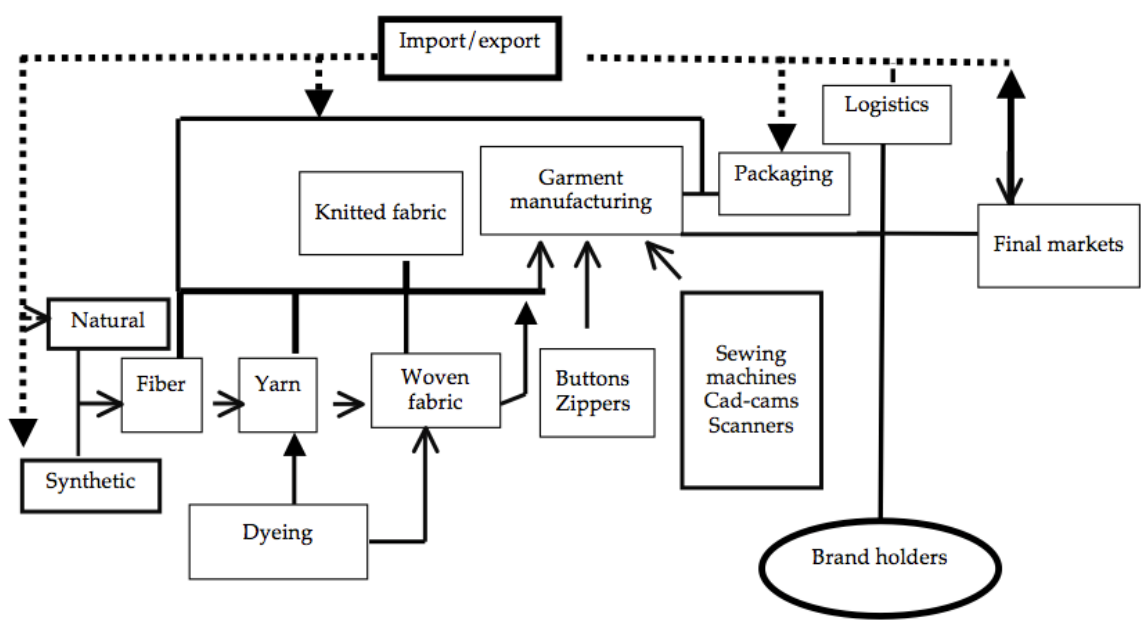


The industrialized economies of South Korea and Taiwan consciously drove institutional change and evolved their technological capabilities to raise the competitiveness of their national firms. For example, both targeted domestic R\&D to acquire and evolve technologyintensive activities that allowed them to eventually catch up with and leapfrog over early movers in several industries. Samsung's leadership in memory chips and Taiwan Semiconductor Manufacturing Corporation's frontier status in logic chips are examples (see Rasiah, Yap et al., 2015). Instead of leaving it to markets, which are prone to failure when it involves the promotion of technical change, Pakistan should adopt a proactive industrial policy to stimulate industrialization and structural change from low- to high-value added activities.

\section{Conclusion}

We have seen that manufacturing was never a major sector in Pakistan. While being confined to low-value added activities, it has started to contract since 2005. Specialization in resource-based yarn and cloth and in clothing production has meant that the industry has remained in a slow growing market niche. Industrial deepening from low- to high-value added activities are essential if manufacturing is to play the engine-of-growth role that it did for South Korea to stimulate rapid GDP growth. Any attempt to make manufacturing the engine of growth so as to engender conditions for rapid growth and structural change will require introducing a carefully crafted industrial policy that takes account of existing and future endowments.

The existing disincentives facing the sector must also go, while exchange and interest rates must be slightly regulated to support the manufacturing sector. This is what South Korea did during the early years of rapid growth in the 1970s. In addition, there must be initiatives to stimulate a structural shift from low-technology to medium- and hightechnology industries. The government will have to gradually increase its emphasis on R\&D activities, including designing, with grants and incentives carefully allocated and regulated to ensure strong industrydriven appropriation.

The formulation of industrial policy to stimulate industrialization will require the development of industrial zones, science and technology parks, and airports and seaports with good infrastructure. It is important that good basic and high-technology infrastructure is developed in 
potentially well-endowed areas as they are critical in providing the synergy required to support manufacturing.

The government should simultaneously expand technical and vocational education in schools, and support R\&D activities in universities that are targeted at commercialization. Science parks should be developed in strategic locations so that the R\&D undertaken in universities and laboratories is either channeled to upgrade existing firms or launched as new start-ups to generate commercial products as well as products and services targeted at improving public welfare.

Since subsidized finance is critical to support these activities, funds must be carefully accounted to ensure that all rents are appropriated productively, and the steering of industrial policy targets is reoriented quickly to avoid costly losses. Such calibration exercises must be done at regular intervals, given the uncertainty gap between plan and reality. 


\section{References}

Abramowitz, M. (1956). Resource and output trends in the United States since 1870. American Economic Review, 46(2), 5-23.

Amsden, A. H. (1989). Asia's next giant: South Korea and late industrialization. New York, NY: Oxford University Press.

Amsden, A. H., \& Chu, W.-W. (2003). Beyond late development: Taiwan's upgrading policies. Cambridge, MA: MIT Press.

Bell, M. (1984). Learning and the accumulation of industrial technological capability in developing countries. In M. Fransman \& K. King, (Eds.), Technological capability in the Third World (pp. 187-209). London: Palgrave Macmillan.

Chang, H.-J. (2002). Kicking away the ladder: Development strategy in historical perspective. London: Anthem Press.

Chenery, H. B., Robinson, S., \& Syrquin, M. (Eds.). (1986). Industrialization and growth: A comparative study. New York, NY: Oxford University Press.

Cororaton, C. B., Salam, A., Altaf, Z., Orden, D., ... Nazli, H. (2008). Cotton-textile-apparel sectors of Pakistan: Situation and challenges faced (Discussion Paper No. 00800). Washington, DC: IFPRI.

Dahlman, C. J. (1984). Foreign technology and indigenous technological capability in Brazil. In M. Fransman \& K. King (Eds.), Technological capability in the Third World (pp. 317-334). London: Palgrave Macmillan.

Fagerberg, J. (2006). Innovation: A guide to the literature. In J. Fagerberg, D. Mowery, \& R. Nelson (Eds.), The Oxford handbook of innovation (pp. 1-27). Oxford: Oxford University Press.

Feldman, G. A. (1928). On the theory of growth rates of national income. In N. Spulber (Ed.), Foundations of Soviet strategy for economic growth: Selected Soviet essays, 1924-1930 (Repr. 1964). Bloomington, IN: Indiana University Press.

Gerschenkron, A. (1962). Economic backwardness in historical perspective. Cambridge, MA: Harvard University Press. 
Hamilton, A. (1791). Report on manufactures. Address to the House of Representatives, 5 December. Retrieved from http://www.constitution.org/ah/rpt_manufactures.pdf

Hussain, S., \& Ahmed, V. (2011). Experiments with industrial policy: The case of Pakistan (Working Paper No. 124). Islamabad: Sustainable Development Policy Institute.

Johnson, C. (1982). MITI and the Japanese miracle: The growth of industrial policy, 1925-1975. Stanford, CA: Stanford University Press.

Kaldor, N. (1957). A model of economic growth. The Economic Journal, 67(268), 591-624.

Kaldor N. (1967). Strategic factors in economic development. Ithaca, NY: Cornell University Press.

Kalecki, M. (1976). Essays on developing economies. Brighton: Harvester Press.

Lall, S. (1992). Technological capabilities and industrialization. World Development, 20(2), 165-186.

Lall, S. (2000). The technological structure and performance of developing country manufactured exports, 1985-1998. Oxford Development Studies, 28(3), 337-369.

Lall, S., \& Weiss, J. (2004). Industrial competitiveness: The challenge for Pakistan (Seminar Paper). Islamabad: Asian Development Bank.

List, F. (1885). The national system of political economy (transl. S. Lloyd). London: Longmans, Green and Co.

Mahalanobis, P. C. (1955). The approach of operational research to planning in India. Sankhyā: The Indian Journal of Statistics, 16, 3130.

Marx, K. (1957). Capital: Circuits of production. Moscow: Progress Publishers.

Nelson, R. (2008). Economic development from the perspective of evolutionary economic theory. Oxford Development Studies, 36(1), 9-22. 
Pakistan, Ministry of Finance. (2014). Pakistan economic survey 2013-14. Retrieved from http://www.finance.gov.pk/survey_1314.html

Rasiah, R. (1994). Capitalist industrialization in ASEAN. Journal of Contemporary Asia, 24(2), 197-216.

Rasiah, R. (1995). Foreign capital and industrialization in Malaysia. Basingstoke: Palgrave Macmillan.

Rasiah, R. (1996). Manufacturing as engine of growth and industrialization in Malaysia. Managerial Finance, 22(5), 87-117.

Rasiah, R. (2004). Technological capabilities in East and Southeast Asian electronics firms: Does network strength matter? Oxford Development Studies, 32(3), 433-454.

Rasiah, R. (2007). The systemic quad: Technological capabilities and economic performance of computer and component firms in Penang and Johor, Malaysia. International Journal of Technological Learning, Innovation and Development, 1(2), 179-203.

Rasiah, R. (2008). Ownership, institutions and technological intensities: Automotive and electronics firms in East and Southeast Asia. In P. Arestis \& J. Eatwell (Eds.), Issues in finance and industry: Essays in honor of Ajit Singh. London: Palgrave Macmillan.

Rasiah, R., Singh, A., \& Ernst, D. (2015). Alice Hoffenberg Amsden: A consummate dirigiste on latecomer economic catch-up. Institutions and Economies, 7(1), 1-8.

Rasiah, R., Yap, X. S., \& Yap, S. F. (2015). Sticky spots on slippery slopes: The development of the integrated circuits industry in emerging East Asia. Institutions and Economies, 7(1), 52-79.

Reinert, E. S. (2007). How rich countries got rich... and why poor countries stay poor. London: Constable.

Rodrik, D. (2007). One economics, many recipes: Globalization, institutions, and economic growth. Princeton, NJ: Princeton University Press.

Rosenberg, N. (1983). Inside the black box: Technology and economics. Cambridge: Cambridge University Press. 
Rowthorn, R. E. (1975). What remains of Kaldor's Law? The Economic Journal, 85(337), 10-19.

Rowthorn, R. E. (1979). A note on Verdoorn's law. The Economic Journal, 89(353), 131-133.

Schumpeter, J. A. (1961). The theory of economic development: An inquiry into profits, capital, credit, interest, and the business cycle. New York, NY: Oxford University Press.

Singh, A. (1989). Third World competition and deindustrialization in advanced countries. Cambridge Journal of Economics, 13(1), 103-120.

Smith, A. (1776). An inquiry into the nature and causes of the wealth of nations. London: Methuen and Co.

Veblen, T. (1915). Imperial Germany and the Industrial Revolution. London: Macmillan.

Wade, R. (1990). Governing the market: Economic theory and the role of government in East Asian industrialization. Princeton, NJ: Princeton University Press.

World Bank. (2008). World development indicators. Washington, DC: Author.

World Bank. (2014). World development indicators. Washington, DC: Author.

Young, A. A. (1928). Increasing returns and economic progress. The Economic Journal, 38(152), 527-542. 